\title{
FORMATION OF INNOVATION-INVESTMENT INTEGRATION STRATEGY FOR INDUSTRY DEVELOPMENT UNDER GLOBALIZATION CONDITIONS
}

\author{
Yurii Melnyk' ${ }^{1}$, Lidiia Voloshchuk ${ }^{2}$, Tetiana Stepanova ${ }^{3}$
}

\begin{abstract}
The main conditions of industry sustainable development in the globalization conditions include macroeconomic stability in the national space, competitiveness and the internal and external environment efficiency. Solving the strategic tasks that will ensure the industrial complex development, especially in the global macroeconomic space, essentially depends to a large extent on innovation, investment, and integration activities, representing the priority directions in the international environment transformation context. Scientific engineering and technological progress is the driving force enabling the industry development in the national macroeconomic environment. In this aspect of the globalization transformations context, a particularly important role is given to innovation, investment, and integration processes. The purpose of this article is justification of theoretic and methodical bases of forming of innovative-investment integrated strategy for Ukrainian economy's industrial sector development under globalization conditions, aimed at supporting the priority achievement of the strategic orientations of the national economy in the context of the European vector of development, taking into account the influence of the factors of the internal and external macroeconomic environment. Methodology. Materials of periodicals, analytical reviews, statistical data, resources of the Internet are the informational and methodological basis of the investigation. The research is based on general scientific and special methods, such as: monographic investigation, generalization, systematization, decomposition, factor analysis, economic-statistical analysis, logical-meaningful modelling. These allowed outlining the basic features and principles of the native industrial economy sector innovative-investment integrated strategy forming under the globalization conditions. The results. Innovation-investment integration strategy is a strategic document for the priority development of the industrial sector of the national economy. This is the source of the accumulation of strategic information and management methods for the future sustainable position of the industrial sector of the country. The developed methodical principles of forming an innovation-investment integration strategy for industry development under globalization conditions provide a phased decomposition of the strategic purpose, which provides an opportunity to determine the most effective directions of industry development, taking into account the input and output parameters of the strategy. The strategy allows assessing the export potential of the national economy's industrial sector, to form export-import orientations and an adequate mechanism of foreign economic activity under conditions of the free trade zone development with the European Union countries and other international environment countries. Practical implications. The process of forming an innovation-investment integration strategy in the national economy industrial segment will enable the development of appropriate elements of the macroeconomic environment under globalization conditions. Value/originality. The strategy elaborates on how strategic management of innovation and investment integration processes in the industry will take place to ensure its effective functioning. Innovationinvestment integration strategy allows assessing the export potential of the national economy's industrial sector, forming an export-import strategy and an adequate mechanism of foreign economic activity under the free trade zone development with the European Union countries and other countries of the international environment.
\end{abstract}

Key words: innovation process, investment process, integration process, strategy, industry.

JEL Classification: F15, F36, L69, M11, O29, O33

\footnotetext{
Corresponding author:

${ }^{1}$ Odessa National Academy of Food Technologies, Ukraine.

E-mail: 9701080@ukr.net

${ }^{2}$ Odessa National Polytechnic University, Ukraine.

E-mail: 1.a.voloschuk@gmail.com

${ }^{3}$ Odesa I.I. Mechnikov National University, Ukraine.

E-mail: stepanovatv@ukr.net
} 


\section{Introduction}

The innovation process embodies a complex set of scientific and technical, technological and structural transformations running in the innovation process; it is a process of thinking product gradual transformation into the research development result (Grigoriev, 2017).

The innovation process basic characteristic, therefore, shall be the scientific, technical or technological novelty, which will provide the national macroeconomic environment subjects' modern needs.

The investment process is a purposeful systemic process of attracting and using all types of property, financial and intellectual resources that are transferred to the national economic complex's relevant objects in order to create added value and meet the society's social and economic needs.

The integration process represents a purposeful convergence or system interaction between macroeconomic environment's economic units in order to achieve quantitative and qualitative assessment of their activities. Modern integration processes inherent to the international macroeconomic environment have replaced the disintegration processes that negatively influenced the social development.

In the context of strengthening globalization processes, significantly updated are the issues of national high-tech industry sector development investments-and-innovation support with the effective use of material, financial, and intellectual resources. The national economy main advantages are: natural and labour resources availability, a favourable territorial location, considerable research potential, the presence and successful development of industrial segments potential, etc.

In today's conditions, the national environment is the one enabling both domestic and international investors. These recent years, the national macroeconomic environment provides economic growth (gross domestic product is $3.8 \%$ ), the national economy subjects' effective demand is growing, the domestic consumer market increases, the banking system is stable and developing, the prognosticated national currency rate and inflation index are also increasing. Capital investments show growth of more than 26\% in 2018. According to the State Statistics Service of Ukraine, analytical indicators, which characterize the industrial products' manufacturing by main industrial groups for the period of 2014-2018, got values shown in Table 1. These indicators (determined without taking into account the temporarily occupied territory of the Autonomous Republic of Crimea, the Sevastopol city, and temporarily occupied territories in the Donetsk and Luhansk regions) do testify the positive results of transformational changes in the national macroeconomic environment.

In order to prioritize the vector orientation strategic benchmarks achievement, the national macroeconomic environment requires the innovation-investment integration strategy formation for the industrial development in a globalizing environment.

\section{Conceptualization of the relationships in the innovation-investment integration strategy}

The innovation-investment integration process embodies a complex combination of innovations and investments with the purposeful interaction between the macroeconomic environment's economic units.

The regulatory and legal framework for the innovationinvestment integration strategy formation to enable the industry's development in the globalization conditions is based on the Laws of Ukraine "On Innovation Activity" (On innovation activity, 2012) and "On Investment Activity" (On investment activity, 2017). The Law of Ukraine "On Investment Activity" defines the investment activity general legal, economic, and social conditions on the territory of Ukraine. The law is aimed at ensuring equal protection of the rights, interests, and property of investment activity subjects, regardless of ownership type, as well as the effective investments into the national economy, the development of international economic cooperation and integration (On investment activity, 2017).

The investment activity is an objective process, bearing its own purpose and logic, and developing in the corresponding regularity; thus it plays a significant

Table 1

Industrial product manufacture indexes by the main industrial groups, \%

\begin{tabular}{|l|c|c|c|c|c|}
\hline \multirow{2}{*}{\multicolumn{1}{c}{ Indicator }} & \multicolumn{3}{c|}{ Years } & January- \\
\cline { 2 - 6 } & 2014 & 2015 & 2016 & 2017 & 6 \\
September 2018 \\
\hline Industry & 2 & 3 & 4 & 100,4 & 101,8 \\
\hline Average consumption period products & 89,9 & 87,0 & 102,8 & 100,2 & 101,8 \\
\hline Investment products & 91,6 & 90,6 & 102,7 & 110,6 & 106,0 \\
\hline Short-term consumptions products & 10,7 & 85,3 & 101,7 & 104,0 & 98,5 \\
\hline Long-term consumptions products & 88,7 & 89,0 & 104,4 & 113,9 & 100,0 \\
\hline Energy & 85,5 & 80,8 & 99,7 & 92,3 & 102,3 \\
\hline
\end{tabular}

Source: formed on the basis (Official site of the State Statistics Service of Ukraine) 
role in the economic units' activity. By its economic component, the investment embodies the shifting from current date material, financial, and intellectual resources consumption for the purpose of obtaining income in future periods.

The Law of Ukraine "On Innovation Activity” defines the legal, economic, and organizational foundations of innovation activity state regulation in Ukraine, establishes the innovation processes stimulation by the state and aims at supporting the Ukrainian economy development in an innovative way. Under this Law, the state support is provided to business entities of ownership forms implementing innovative projects in Ukraine and enterprises of all ownership forms that have the status of innovative ones (On innovation activity, 2012).

Thus, the innovation-investment process begins with the formation of an innovation-investment strategy. The formation of an innovation-investment integration strategy for the development of industry in a globalized environment depends on: political, legal, financial and economic and infrastructure conditions. In Figure 1 we defined the conditions for the formation of innovation and investment integration strategy for the development of industry in a globalizing environment.

The innovation-investment integration strategy is understood as a complex of long-term strategic goals and the choice of the most effective ways to achieve them with respect to the influence of internal and external macroeconomic environmental factors. The innovation and investment integration strategy formation for the industry's development in a globalized environment is a complex management process based on the prediction of certain conditions for the innovation and investment activities' implementation both as to the market environment as a whole and in the context of its individual segments, taking into account the integration orientation. Innovationinvestment integration strategy is always formed within the framework of the industry development general strategy, well-agreed with its implementation principles, goals, stages, and timing.

In the global international macroeconomic space, there exists a large number of innovation and investment integration processes' management forms at the appropriate levels of entity management taking into account the segment component. The management is carried out starting from structural subdivisions of economic units to the state as a whole, and the state carries out the targeted regulatory policy under the influence of relevant internal and external factors. The targeted state regulatory policy basic task is to support innovation and investment integration activity in the country's scientific and technical potential development taking into account the current international situation.

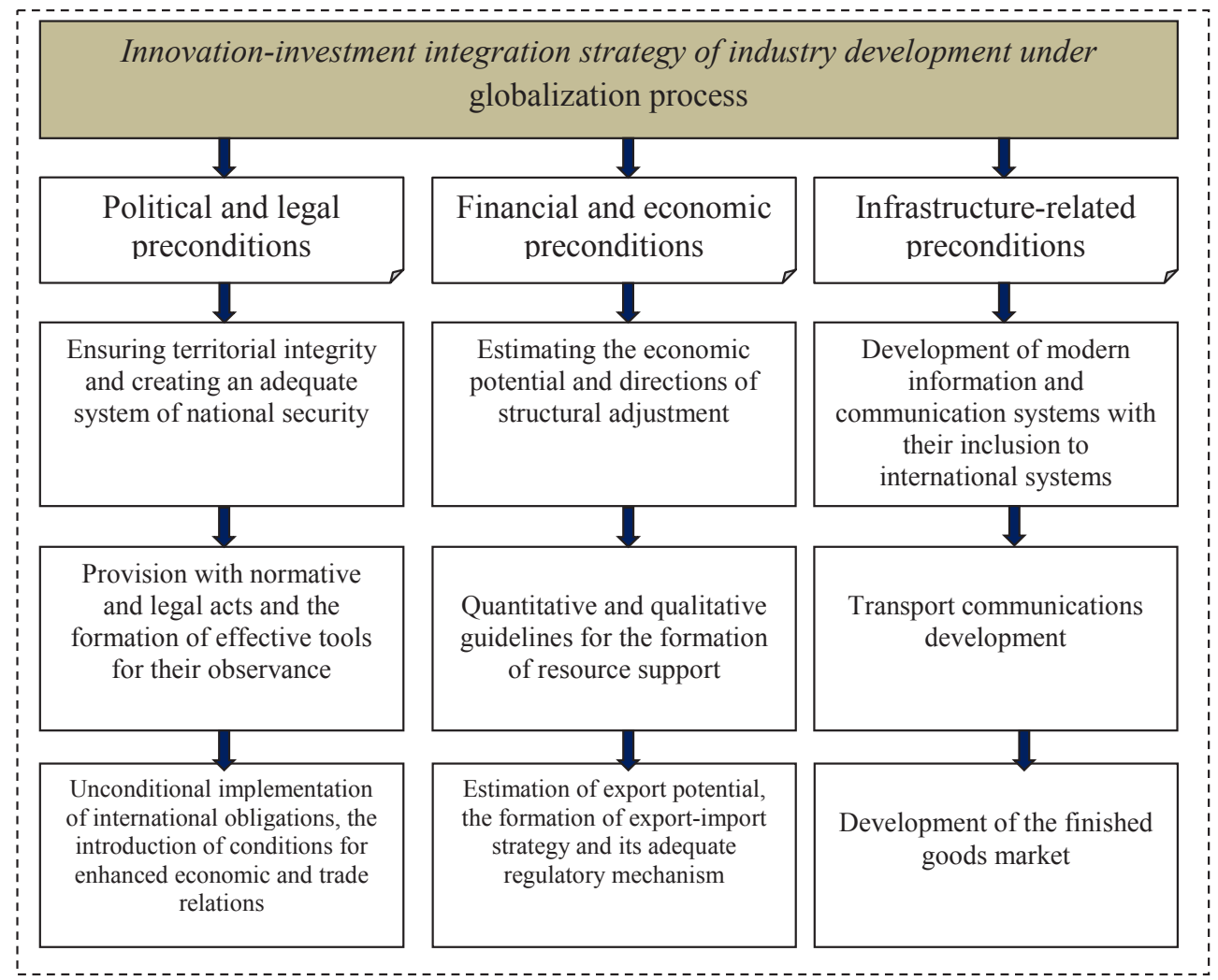

Figure 1. Conditions to form an innovation-investment integration strategy for the industry's development in a globalizing environment 


\section{Decomposition of the purpose of innovation and investment integration strategy for the industry}

The innovation and investment integration strategy's main objective at the industry is to develop its potential. The strategy's main purpose is subdivided into levels and presented in Figure 2.

The decomposition is a process of some research object logical partitioning that allows us to consider any systems consisting of separate interconnected subsystems. Subsystems can also be disassembled into even smaller segments. In theoretical and practical studies, such systems include: concept, principles, tasks, processes, phenomena, etc. The decomposition provides a detailed study of the research object thus representing a system analysis tool used to structure the defined goals, objectives, contradictions, problem issues, relevant decisions, priority development strategies, and other aspects of the functional and structural approach to the existing systems' research analysis or the modern systems synthesis. The outer shape of the decomposition has a schematic look.

The main approaches to the decomposition of innovation and investment integration strategy goal in the industry are: aggregated, differentiated, targeted, detailed, and integration approaches.

The aggregated approach defines the indicators to be achieved as a result of the development of innovation and investment integration strategy implementation. Indicators are aggregated when they are grouped, synthetic, generalized and characterize the industry structural units' development. Aggregated elements in one or another unit may be the following: overall efficiency of asset utilization; fixed assets use intensification and indicators; indicators of working resources use efficiency; indicators of finished products volume increase or decrease and product trading; reserves of production capacities for innovative products development; increasing the finished products competitiveness; indicators and assessment tools as to labour productivity, its reserves, and increasing factors; structure of the industrial products prime cost; indicators of the industrial production profitability; increase in the management system efficiency at all levels; other indicators.

The differentiated approach reveals data per every functional unit: provision process functional-structural model; production process functional-structural model; trading process functional-structural model.

The target approach specifies for each segment the relevant functional and structural models' elements, for example, the production process segments are: the main, auxiliary, and service processes.

The detailed approach reveals the indicators for each part of the relevant segment and evolves the specific information, for example, the finished product quality at all lifecycle stages. It should be noted that the industrial products quality is formed at four stages of its lifecycle: study, design, production, and consumption and, in the first two stages, the highest percentage of the industrial product quality level is formed.

The integration approach ensures the interconnection between the management system individual differentiated elements and functions in the industry. Integration is one of the important efficiency factors as to our country's industry functioning, including

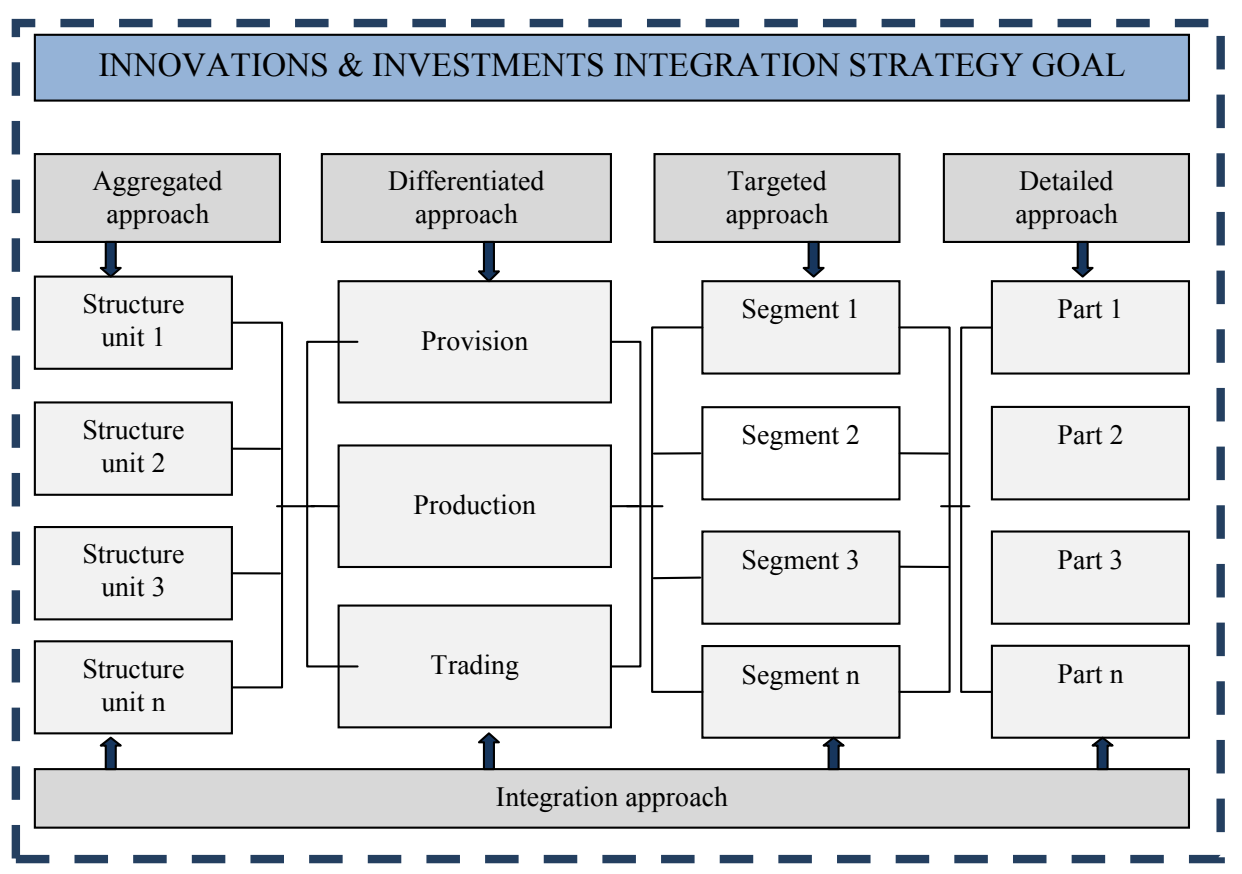

Figure 2. Decomposing the innovation-investment integration strategy goal in industry 
its ability to rapid innovations implementation that will ensure the industry innovation and investment integration strategy goal achievement.

The proposed decomposition allows linking the goals and their implementation tools for each structural unit while taking into account the entity's strategic development priority level due to the by goals achieving tools coordination by relevant resources type.

It should be noted that the formation of an innovation-investment integration strategy for industry development under globalization conditions requires appropriate support at the state institutions level, namely: fundamental and applied researches qualitytargeting development; a new scientific formation industry specialists training providing; support to strategic innovation and investment projects; support to national and international scientific, technical and technological specialization and cooperation; comprehensive support in the innovative-investment industrial objects (business incubators, technoparks, technopolises, innovation centres)creation and functioning; using financial and economic instruments, creation of a favourable macroeconomic environment that provides innovation and investment activity of the national economy's industrial complex.

In the global scientific environment, the innovationinvestment areas' state regulation and support measures are determined by the direct and indirect action influences.

The ratio of state regulation direct or indirect institutional influence is determined by the national macroeconomic environment's state and conceptual foundations based on market principles.

Decision-making in the national economy industrial sector as to the innovation and investment activity relies on the issues related to the choice of alternative options for the industrial enterprises' development in a competitive environment influenced by the relevant factors (political, legal, financial, economic, social etc.).
In the industrial enterprises' innovation and investment integration strategic development study, the mechanism of innovation-investment sphere state regulation with the macroeconomic environment subjects' engagement to the country's economic innovation and investment potential increase is of prime importance. The need for state influence on innovation and investment activity under current conditions is due to factors not inherent to a market situation environment but having an objective significance.

Figure 3 below shows schematically the financial and economic consequences of an innovation and investment integration strategy selection by the national economy's industrial sector.

It should be noted that the innovation and investment activity lack in future periods involves a reduction in income due to non-current assets moral and physical depreciation, deterioration in the process of provision, production, and sale that ultimately calls into question the future functioning of such national economy's industrial sector economic unit.

An active innovation and investment integration strategy provides a gradual increase in revenues to the inter-sectoral investments level, involves the formation and implementation of various innovationinvestment projects or programs. An active innovation and investment integration strategy involves the active behaviour of the national economy's industrial sector subjects in the domestic and foreign markets.

A passive innovation-investment integration strategy involves maintaining the industrial enterprises' strategic development unchanged level and thus leads to a lagging behind the inter-sectoral level, in the future periods will have the same consequences.

An efficient innovation and investment integration strategy is associated with the scientific, technical and technological process, implementing fundamentally new technological solutions and creating an innovative

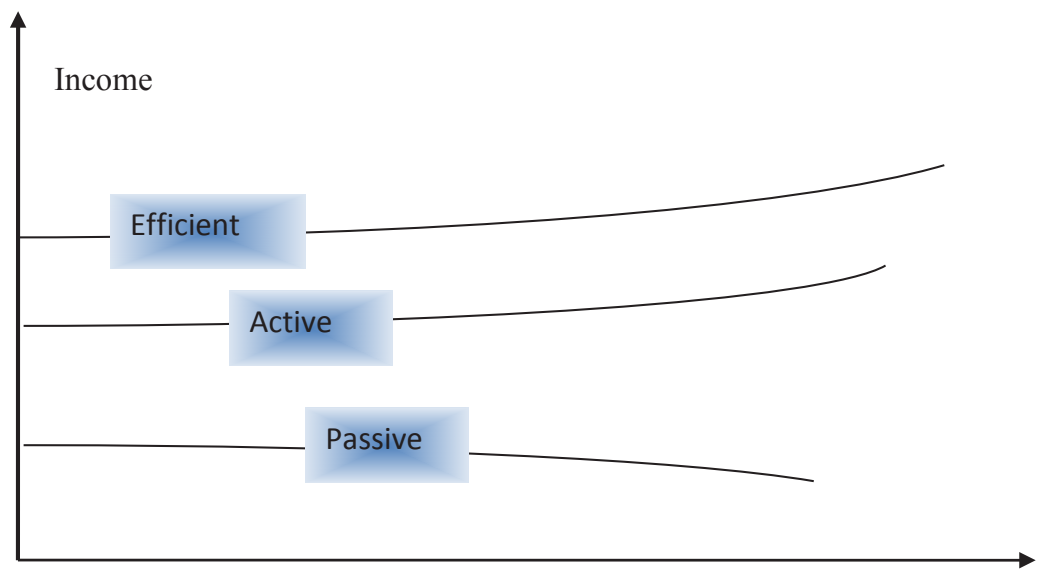

Period

Figure 3. Influence of innovation and investment integration strategy on the national economy's industrial sector incomes 
product. The innovation and investment integration strategy elements can be: intangible products; industrial production equipment and processes; industrial infrastructure; modern organizational, technical and technological landmarks of any character; logistic components; innovative product and so on. An efficient strategy involves the effective behaviour of the national economy's industrial sector subjects in the domestic and foreign markets, which will provide the most effective, quantitative and qualitative orientation.

Important and interconnected conditions for innovation and investment activities' implementation by the national economy industrial sector subjects in the market environment should be: availability of free capital or resources from a potential innovator or investor, desire to place free resources on acceptable conditions in the national economy industrial sector; political stability in the country and an adequate national security system; legal security and safety that promote the efficient allocation and movement of capital in all areas.

The innovation and investment activity stages are provided by: industrial enterprises, innovators, investors, subjects of innovation infrastructure, state institutions, regional and local structures.

The identified actors operate at different stages of the innovation and investment process, their activities' purpose and tasks varying. They reflect their own specific interest that causes a lot of innovation and investment integration strategy dimensionality. But the main driving motive of these entities' whole activity as involved in the innovation and investment process is the possibility of increasing value-added and obtaining, on this basis, entrepreneurial results in their specific application areas of activity taking into account the respective risks.

In the innovation-investment integration strategy, the involved subjects' interest coordination requires the identification of conflicting interests' carriers. The scientific research interested subject is the national economy's industrial segment. The capital owner has own special interests that not always coincide with the general motives of the national economy's industrial sector. Intermediate positions between innovators, investors, and industry are occupied by actors of innovation infrastructure, state institutions, regional and local structures.

\section{An innovative-investment integrated strategy for industry's development: key features and stages of forming}

The innovation and investment integration strategy is formed in the sector of mutual interests' crossing-over between the industrial enterprises and all this process participants. The ability to form a strategy depends on the priority of the partners' mutual interests coordination, the ability to see the innovation-investment object from the strategic position and, first of all, ability to assess the investment attractiveness.

The variety of approaches to the investment and innovation strategy interpretation, as well as the nature of their interconnections, only emphasizes the versatility of the investment-innovation strategy definition (Khustova, 2015).

An innovation-investment strategy is a specific tool for providing a strategy for the national economy's industrial sector growth or stabilization by investing capital in the economic industrial units' effective development, expanded reproduction of non-current assets, the creation of innovations, which in future periods will ensure the competitive advantages formation in the country's industrial sector.

It is underlined that the innovation and investment integration strategy is developed at different levels and takes into account the various components; therefore the following classification of the national economy industrial sector investment-innovation integration strategy is proposed:

- local integration strategy: at the regional level; at the industry level; at the enterprise level;

- national integration strategy: at the inter-sectoral level; at the interregional level; at the industrial subjects' level; - global integration strategy: at the national level; at the inter-sectoral level; t the interregional level; at the level of industrial enterprises.

It is well-known that macroeconomic growth in the national environment is based on a combination of economic units' performance extensive and intensive indicators. The national economy's industrial sector is of a vectorial importance for the country's sustainable development. The industry represents a priority vector for the value-added creation, thus involved into sectoral and inter-sectoral interconnections, has a significant impact on the activity of the national economy's individual economic units.

In the international macroeconomic environment, the possibility of increasing the industrial products manufactured volume at the extensive factor expense is limited; therefore, priority strategic guidelines for the economy industrial sector effective development acquire modern intensive components: improving quality and productivity. The intensive components also include the innovative activities results that increase the return on fixed assets and working capital and provide priority opportunities for the strategic high-quality growth of the country's industrial sector results.

In Ukraine, the industrial sector accounts for about $31 \%$ of GDP, over $19 \%$ of the working population in the country are employed in the industry, thus a significant share in its branches structure belongs to the metallurgical segment, machine building, electricity and instrument manufacture. In 2015-2018, observed is a tendency to increase the national economy's industrial sector share in the country's gross domestic product. 
Dynamic analysis of the industrial sector innovative activity financing sources and structure in the national economy of Ukraine in 2000-2017 (Table 2) reflects the minimum share of the state in those finances. The given data by indicators are presented without taking into account the temporarily occupied territory of the Autonomous Republic of Crimea, Sevastopol city, and temporarily occupied territories in the Donetsk and Luhansk regions of Ukraine.

According to the State Statistical Service of Ukraine data analytical indicators show that the essential innovative activity financing source in the national economy's industrial sector during 2000-2017 is the industrial activity subjects own resources, which accounts for more than $2 / 3$ of the total volume of expenditures on innovation. The table data indicate that other financing sources do not have a significant impact on the industrial enterprises innovative activity. Foreign investments amount is almost equal to budget financing.

The initiation of any activity kind in the national economy industrial sector is associated with significant capital expenditures in the form of financial, material, and intangible assets necessary for: analytical study of the future economic activity conditions; designing the national economy's industrial segment activity provision process economic cycle; designing the production process economic cycle; designing the commodity products' marketing economic cycle; formation of a management system, i.e. creation of all services at an economic entity, all subsystems and communications between them, including processes that ensure its functioning; formation of a monitoring and control system in order to get and transmit true, unbiased, and complete information to those who finance innovation and investment integration strategy.

Reliable information provides an opportunity to evaluate past, current, and future events, allowing their strategic assessment.

Achieving the goal of the national economy's industrial sector sustainable development depends in many respects on the integration strategy of the country's macroeconomic development. After all, the industrial sector, on the one hand, creates the society life material basis, and on the other, the parameters of economic influence on the internal consumer environment are laid, therefore.

The processes of intra-industry and inter-sectoral integration confirm virtually all the country's economy segments. The integration processes at the sectoral level are carried out in both vertical and horizontal direction. Vertical integration in the industrial sector determines certain economic processes centralization mechanisms in its subjects' activities. But the vertical integration is based on the economic processes' productiontechnological indivisibility in the industrial sector of the economy.

Integration processes at the sectoral level are among the most important factors of the efficient functioning of the country's industry economic units.

Table 2

Sources and structure of the national economy's industrial sector innovative activity financing

\begin{tabular}{|c|c|c|c|c|c|c|c|c|c|}
\hline \multirow{3}{*}{ period } & \multirow{3}{*}{$\begin{array}{c}\text { Total } \\
\text { expenses } \\
\text { amount, } \\
\text { mln UAH }\end{array}$} & \multicolumn{8}{|c|}{ Including financing sources } \\
\hline & & \multicolumn{2}{|c|}{ own } & \multicolumn{2}{|c|}{ State budget } & \multicolumn{2}{|c|}{ Foreign investors } & \multicolumn{2}{|c|}{ Other sources } \\
\hline & & mln UAH & $\%$ & mln UAH & $\%$ & mln UAH & $\%$ & mln UAH & $\%$ \\
\hline 1 & 2 & 3 & 4 & 5 & 6 & 7 & 8 & 9 & 10 \\
\hline 2000 & 1757,1 & 1399,3 & 79,64 & 7,7 & 0,44 & 133,1 & 7,57 & 217 & 12,35 \\
\hline 2001 & 1971,4 & 1654 & 83,90 & 55,8 & 2,83 & 58,5 & 2,97 & 203,1 & 10,30 \\
\hline 2002 & 3013,8 & 2141,8 & 71,07 & 45,5 & 1,51 & 264,1 & 8,76 & 562,4 & 18,66 \\
\hline 2003 & 3059,8 & 2148,4 & 70,21 & 93 & 3,04 & 130 & 4,25 & 688,4 & 22,50 \\
\hline 2004 & 4534,6 & 3501,5 & 77,22 & 63,4 & 1,40 & 112,4 & 2,48 & 857,3 & 18,91 \\
\hline 2005 & 5751,6 & 5045,4 & 87,72 & 28,1 & 0,49 & 157,9 & 2,75 & 520,2 & 9,04 \\
\hline 2006 & 6160 & 5211,4 & 84,60 & 114,4 & 1,86 & 176,2 & 2,86 & 658 & 10,68 \\
\hline 2007 & 10821 & 7969,7 & 73,65 & 144,8 & 1,34 & 321,8 & 2,97 & 2384,7 & 22,04 \\
\hline 2008 & 11994,2 & 7264 & 60,56 & 336,9 & 2,81 & 115,4 & 0,96 & 4277,9 & 35,67 \\
\hline 2009 & 7949,2 & 5169,4 & 65,03 & 127 & 1,60 & 1512,9 & 19,03 & 1140,6 & 14,35 \\
\hline 2010 & 8045,5 & 4775,2 & 59,35 & 87 & 1,08 & 2411,4 & 29,97 & 771,9 & 9,59 \\
\hline 2011 & 14333,9 & 7585,6 & 52,92 & 149,2 & 1,04 & 56,9 & 0,40 & 6542,2 & 45,64 \\
\hline 2012 & 11480,6 & 7335,9 & 63,90 & 224,3 & 1,95 & 994,8 & 8,67 & 2925,6 & 25,48 \\
\hline 2013 & 9562,6 & 6973,4 & 72,92 & 24,7 & 0,26 & 1253,2 & 13,11 & 1311,3 & 13,71 \\
\hline 2014 & 7695,9 & 6540,3 & 84,98 & 344,1 & 4,47 & 138,7 & 1,80 & 672,8 & 8,74 \\
\hline 2015 & 13813,7 & 13427 & 97,20 & 55,1 & 0,40 & 58,6 & 0,42 & 273 & 1,98 \\
\hline 2016 & 23229,5 & 22036,0 & 94,86 & 179,0 & 0,77 & 23,4 & 0,10 & 991,1 & 4,27 \\
\hline 2017 & 9117,5 & 7704,1 & 84,5 & 227,3 & 2,49 & 107,8 & 1,18 & 1078,3 & 11,83 \\
\hline
\end{tabular}

Source: formed on the basis (Official site of the State Statistics Service of Ukraine) 
In the conditions of international competition intensification, intra-industry integration provides the opportunity to manoeuvre the entities' assets in order to effectively use them.

The integration aspects of innovation and investment strategy are characterized by the following:

- joint research and applied research;

- ability to create or improve competitive industrial technologies, commodity products, etc.;

- most rational use of scientific and technical cooperation results;

- efficient allocation of resource support used in industrial activities;

- high adaptability and flexibility at changing conditions in the internal and external environment;

- quantitative and qualitative orientation on the national economy's industrial sector segments activity results;

- sharing and commercialization of applied research and development results;

- implementation of innovation and investment activity priority directions;

- joint creation of innovation and investment infrastructure;

- mutual support in the financial and material relations between economic units in the industry.

The integration processes' positive influence on the national economy's industrial segment development lies in the fact that the subjects do provide the innovation-investment component application in their economic activity that ultimately positively affects the effective functioning of the country's macroeconomic environment.

In today's transformational and aggressive conditions, the innovation and investment technologies development and implementation, the creation of appropriate facilities and equipment are associated with significant costs, excessive for most of the national economy's industrial segment subjects.
Sources of innovation and investment integration strategy financing are defined in Figure 4.

The usual practice in implementing innovationinvestment industrial projects is to attract external national and international capital in any form. In accordance with the current legislation, the financing sources for the innovation and investment integration strategies' implementation may be: enterprise's own or borrowed resources; funds of individuals and legal entities; resources from the State Budget of Ukraine and local territorial communities budgets; resources of specialized state and municipal innovative financial and credit institutions and other sources.

The attracted resources use efficiency at the innovation and investment integration strategy objects in the national economy's industrial segment is confirmed by the results of industry economic activity, which ultimately integrate into the financial, economic, social, and environmental effects.

In practice, the innovation and investment integration strategies funding sources are closely interconnected and used in a complex while resource mobilization process to form a common strategy for the national industrial entity's development. The strategy innovationinvestment regulation, rational by the results and balanced by the flexibility degree is impossible without regulatory and normative support.

Legal regulation as to the innovation and investment activity is carried out, firstly, by general civil and economic legislation and, secondly, by special laws regulating innovation and investment activity.

The process of forming the national economy's industrial segment innovation and investment integration strategy embodies a series of interconnected stages, which are presented in Figure 5.

The formation of innovation and investment activity strategic goals in the national economy's industrial sector is carried out at the innovation and investment integration

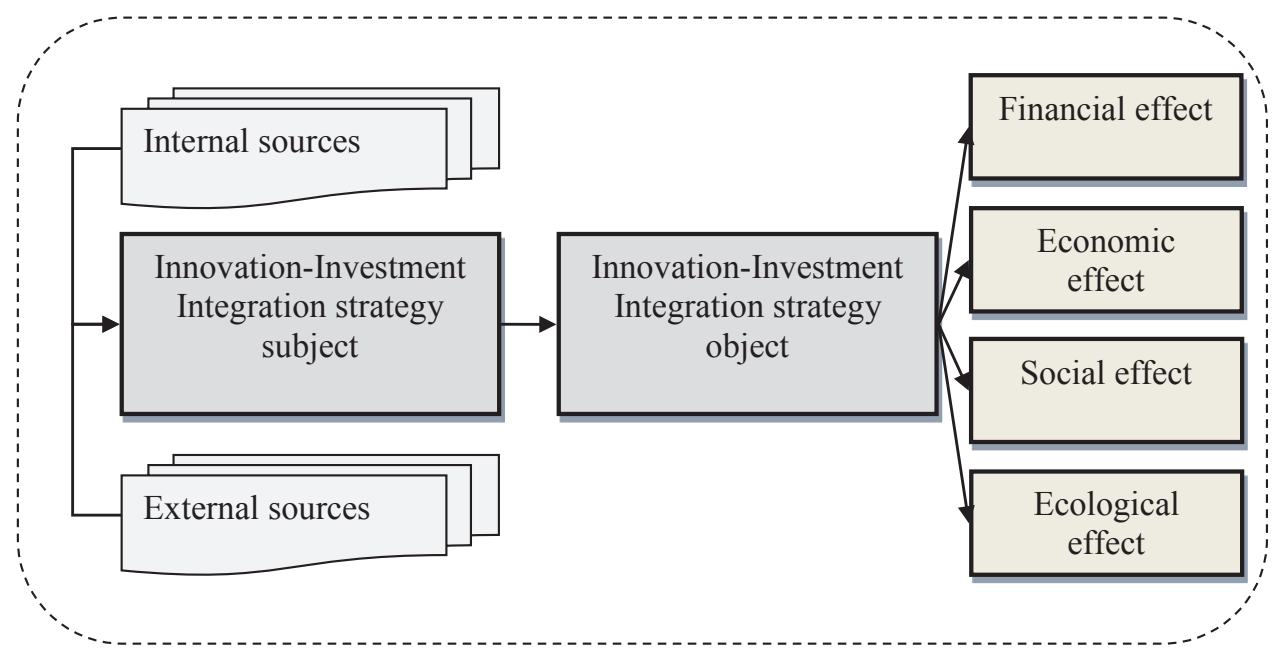

Figure 4. Innovation-Investment Integration strategy financing sources 


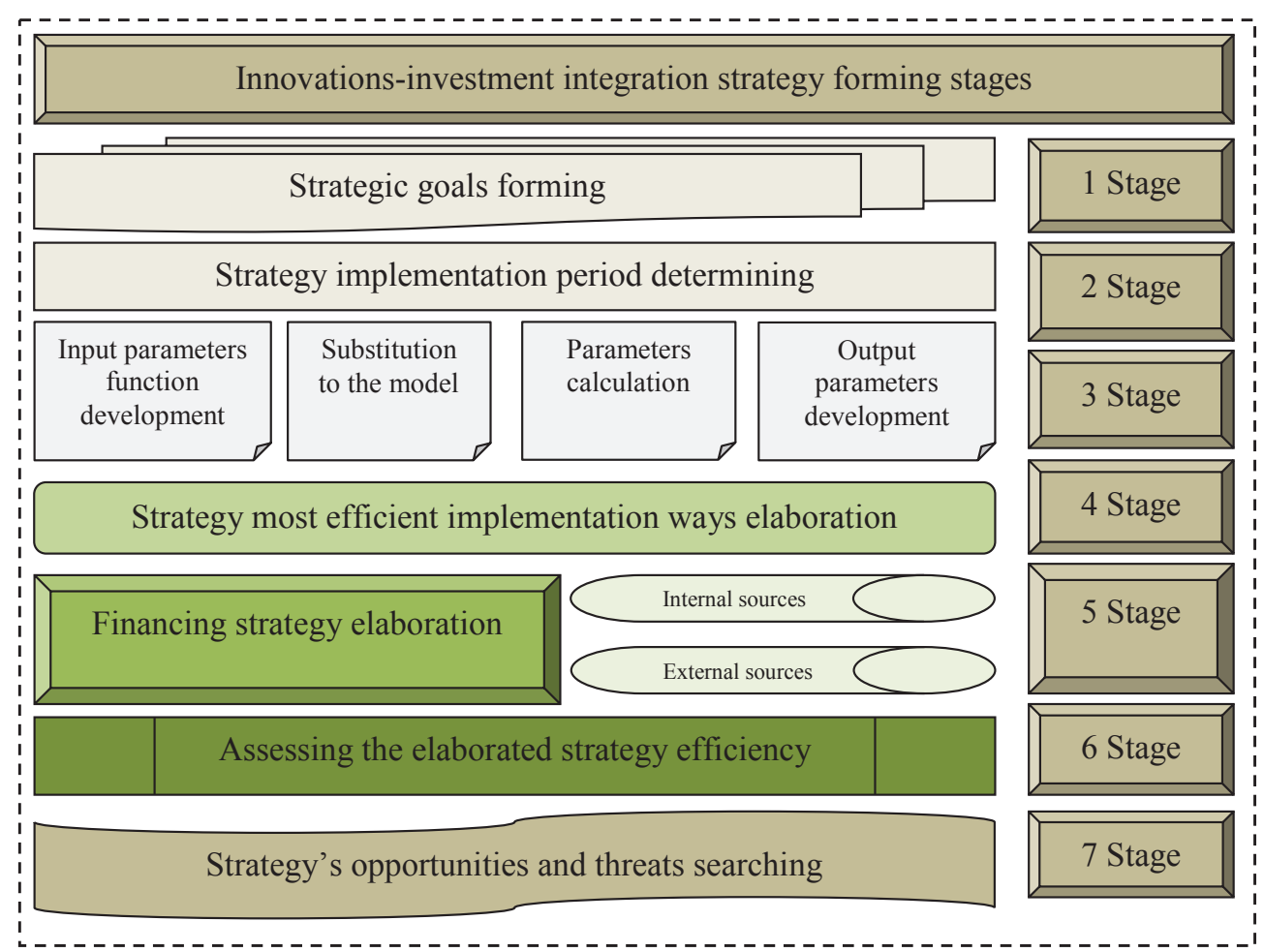

Figure 5. Forming the national economy's industrial segment innovation and investment integration strategy: process stages

strategy elaboration first stage and should proceed, first of all, from the economic subject development strategy goals system: providing the own capital growth; increase in the level of income from innovation and investment integration activities; changes in proportions between real and financial investment in industry; change in capital investments' technological and reproductive structure; change in the intra-industry and branch orientation of innovation-investment programs; society socio-economic needs satisfaction.

The second stage defines the general period of innovation and investment integration strategy formation, which depends on the following conditions: - predictability of the national economy's development as a whole and innovation and investment environment particularly;

- the safe orientation of innovative, investment, and integration processes;

- development strategy period and its duration;

- economic entity sectoral affiliation and its size.

This strategy development stage involves establishing the sequence and timing to achieve individual goals and to address identified strategic objectives. In the innovation-investment integration strategy targeted formulation process, the internal and external synchronization of actions in time is provided. The strategy internal synchronization involves coordinating in time the implementation of certain areas of innovation, investment, and integration processes, as well as the necessary support creation. The strategy's external synchronization involves coordinating in time the innovation-investment integration strategy implementation with the industrial entity development strategy, as well as with predicted changes in the macroeconomic environment.

At the third stage, the logic-mathematical apparatus is used that characterizes the industrial development innovation-investment integration strategy input and output parameters.

At the following two stages, the development of the most effective ways to implement the innovation and investment integration activities' strategic objectives takes place.

The innovation and investment integration activity strategic directions development is based on the specified activity goals system. In the development process, the following issues are consistently addressed: - identification of a priority innovative project;

- determination of the ratio for any investment forms in the developed strategy period;

- definition of horizontal or vertical orientation integration paths;

- substantiation of innovation and investment integration activity sectoral branch orientation;

- definition of innovation and investment integration activity national and international aspects.

It should be noted that all directions and forms of innovation and investment integration activity in the 
national economy industrial segment are implemented via the intermediary of the appropriate resource provision. Resource provision strategy is an essential element not only in innovation and investment strategy but also in financial one. This strategy formation is intended to ensure uninterrupted innovation and investment integration activities in the foreseen parameters, financial resources efficient use, and maintaining the industry entities' financial stability in future periods.

Resource support is carried out in the following sequence:

- forecasting needs in the total amount of resource support;

- search for internal financing sources;

- search for external financing sources;

- substantiation of methods for financing innovative and investment projects;

- resource structure optimization;

- creating a resource support model.

The developed innovation and investment integration strategy effectiveness assessment is carried out at the sixth stage. The assessment is based on the following basic criteria:

- innovation and investment integration strategy consistency with the national economy industrial sector subject development strategy, consistency and correlation of goals, objectives, principles, directions, and stages of implementation between the identified strategies;

- innovation and investment integration strategy internal balance, to determine how consistently the strategic goals and directions of innovation and investment integration activities are mutually agreed;

- the sequence of innovation and investment integration strategy tasks;

- consistency with the innovation and investment integration strategy external environment estimated as far as it is in line with the predicted changes in economic development, investment climate in the national and international macroeconomic environment;

- the coherence of the innovations and investments market conditions;

- strategy application taking into account the available resources potential, assessment of potential opportunities for the industry as to resources formation at the expense of own sources;

- innovation and investment integration strategy effectiveness is based on determining its application effectiveness, taking into account financial, economic, social, and environmental outcomes.

It should be noted that evaluation requires appropriate methodological support. In today's conditions, it is possible to apply here the strategic assessment methodology at both micro and macro levels.

At the last stage, research is being carried out on the innovation and investment integration strategy opportunities and threats. For a successful implementation of the strategy, the national economy industrial sector subjects should be able to predict the difficulties that may arise while its implementation in subsequent periods, therefore, it is necessary to focus on the threats and opportunities identification. Instrumental support at this stage is such: SWOT analysis, BCG matrix, Ansoff product matrix, SPACE analysis, GE/McKinsey matrix, national products, technologies, organization lifecycle diagrams, Porter's graph "profitability - market share", curve experience, value chain, etc. According to the study results, the innovation-investment integration strategy strengths and weaknesses are determined in real time. The innovation and investment integration strategy strengths and weaknesses to the same extent as threats and opportunities determine the real conditions for its implementation.

Thus, the national economy industrial sector cannot operate effectively under political instability conditions, in the absence of an adequate security system, at the market environment instability and the lack of welldeveloped innovation and investment integration strategy in the context of the national macroeconomic environmental development European vector. The strategy elaborates on how strategic management of innovation and investment integration processes in the industry will take place to ensure its effective functioning. Innovation-investment integration strategy allows assessing the national economy's industrial sector export potential and forming an export-import strategy, as well as an adequate foreign economic activity mechanism in the context of developing a free trade zone with the European Union countries and other countries of the international environment.

\section{Conclusions}

Constant transformational changes in the macroeconomic environment where the industry operates encourage the use of special mechanisms for the innovation and investment integration strategy implementation. The lack of a well-thought-out strategy, periodically adjusted to the changing internal and external environment is a significant disadvantage, which reflects the overall industrial development strategy weakness, which in turn complicates the use of modern advanced competitive technologies, innovative products manufacturing, adopting administrative, industrial, and commercial organizational and technological solutions, which significantly improve the economic activity structure and quality.

The innovation-investment integration strategy is a strategic document for the national economy's industrial sector priority development. This is the source of the strategic information and management methods accumulation for the future sustainable position of the national industrial sector.

The methodical principles on elaborating an innovationinvestment integration strategy for the industry's 
development in a globalizing environment include a phased decomposition of the strategic goal, using aggregated, differentiated, targeted, and detailed approaches, which provides the opportunity to determine the most effective directions of industry development, taking into account the strategy input and output parameters.
The strategy allows assessing the national economy industrial sector export potential, forming exportimport orientations and an adequate mechanism of foreign economic activity when establishing and developing a free trade zone with the European Union and other countries of the international environment.

\section{References:}

Grigoriev, G. S. (2017). Theoretical and methodological principles of state regulation of financial and economic processes in the conditions of globalization: monograph. Kherson: Oldi plus.

Khustova, K. M. (2015). Investment-innovative strategy of the enterprise and approaches to its classification. Financial space, 4(20), 183-187. Retrieved from: https://fp.cibs.ubs.edu.ua/files/1504/15hkmdjk.pdf

Oficijnyj sajt Derzhavnoji sluzhby statystyky Ukrajiny [Official site of the State Statistics Service of Ukraine]. Retrieved from: http://www.ukrstat.gov.ua/

On innovation activity (2012). Law of Ukraine dated 04.07.2002, No 40-IV. Updated: 12/05/2012. Retrieved from: http://zakon.rada.gov.ua/laws/show/40-15 (application date 15.01.2018)

On investment activity (2017). Law of Ukraine dated 18.09.1991 No. 1560-XII. Updated: 12/18/2017. Retrieved from: http://zakon.rada.gov.ua/laws/show/1560-12 (application date 15.01.2018) 